\title{
Dietary baker's yeast sensitizes Ehrlich mammary adenocarcinoma to paclitaxel in mice bearing tumor
}

\author{
MAMDOOH GHONEUM ${ }^{1}$, NARIMAN K. BADR EL-DIN ${ }^{2}$, ASHRAF Z. MAHMOUD ${ }^{3}$, \\ LUCILENE TOLENTINO ${ }^{4}$, DEYU PAN ${ }^{5}$ and TAHIA ALI HASSAN ${ }^{2}$
}

\author{
${ }^{1}$ Department of Surgery, Drew University of Medicine and Science, Los Angeles, CA 90059, USA; \\ ${ }^{2}$ Department of Zoology, Faculty of Science, and ${ }^{3}$ Urology and Nephrology Center, University of Mansoura, \\ Mansoura 35516, Egypt; Departments of ${ }^{4}$ Pathology and ${ }^{5}$ Preventive and Social Medicine, \\ Drew University of Medicine and Science, Los Angeles, CA 90059, USA
}

Received July 18, 2018; Accepted December 13, 2018

DOI: $10.3892 /$ or.2019.7107

\begin{abstract}
Baker's yeast, Saccharomyces cerevisiae, has been shown to sensitize a variety of breast cancer cell (BCC) lines to paclitaxel chemotherapy in vitro. The present study evaluated the ability of $S$. cerevisiae to sensitize BCCs to paclitaxel in animals bearing Ehrlich ascites carcinoma (EAC). Mice bearing EAC were intratumorally injected with dead $S$. cerevisiae $\left(1 \times 10^{7}\right.$ cells $\left./ \mathrm{ml}\right)$ in the presence or absence of low- and high-dose paclitaxel [paclitaxel-L, $2 \mathrm{mg} / \mathrm{kg}$ body weight (BW) and paclitaxel-H, $10 \mathrm{mg} / \mathrm{kg} \mathrm{BW}$, respectively]. At 30 days post tumor inoculation, co-treatment with yeast plus paclitaxel-L showed improvements over paclitaxel-H alone, as measured by tumor weight (-64 vs. $-53 \%)$, DNA damage (+79 vs. $+62 \%)$, tumor cell apoptosis $(+217$ vs. $+177 \%)$, cell proliferation $(-56$ vs. $-42 \%)$ and Ki-67 marker (+95 vs. $+40 \%)$. Histopathology and ultra-structural examinations showed that yeast plus paclitaxel-L enhanced apoptosis in EAC more than paclitaxel$\mathrm{H}$ alone and caused comparable tumor necrosis. We conclude that baker's yeast may be used with low-dose chemotherapy to achieve the same potency as high-dose chemotherapy in mice bearing EAC. This suggests that baker's yeast may be an anticancer adjuvant and may have clinical implications for the treatment of breast cancer.
\end{abstract}

\section{Introduction}

Cancer accounts for 1 in 8 deaths worldwide and is rapidly becoming a global pandemic. Unfortunately, there are two key obstacles to the effective treatment of cancer: drug toxicities and multi-drug resistance (MDR). Current methods

Correspondence to: Dr Mamdooh Ghoneum, Department of Surgery, Drew University of Medicine and Science, 1621 E. 120th Street, Los Angeles, CA 90059, USA

E-mail:mghoneum@ucla.edu

Key words: chemosensitizer, S. cerevisiae, paclitaxel, apoptosis, in vivo for treating cancer with chemotherapy have severe toxicities that can include myelosuppression, neurotoxicity, immunesuppression and mutagenic and carcinogenic effects (1-3). In addition, complete elimination of tumor cells post-treatment with chemotherapy is hindered by the development of MDR. The main cause for the development of MDR in cancer cells has been attributed to the overexpression of ABC drug transporters, resulting in a decrease in drug uptake or an increase in drug efflux from the cancer cells.

Currently, there is increased interest in using and developing natural products that overcome the problems of toxicity and drug resistance of chemotherapy agents. Natural products from several different sources have been identified as potential novel therapeutic candidates for cancer treatment, including products derived from plants, animals, vitamins, minerals and microorganisms (4). These include vitamin E (5), tetrandrine that is a bisbenylisoquinoline alkaloid from the root of Stephenia tetrandra (6), the natural isoflavone compound genistein (7) and green tea that contains flavonoids and catechins (8). In addition, we have developed several natural biological response modifiers (BRMs) which exhibit anticancer effects against several cancer types and have minimal, if any, side effects. These include MGN-3/Biobran, an arabinoxylan from rice bran (9-11); marina crystal minerals (MCM), a crystallized mixture of minerals and trace elements from sea water (12), Thymax, gross thymic extract (13) and PFT, a novel kefir product (14).

Several of the above natural dietary products that have been shown to act as potent anticancer agents have subsequently also been shown to possess effective chemosensitizing properties. For example, MGN-3/Biobran has been shown to sensitize cancer cells to several chemotherapeutic agents such as cisplatin, doxorubicin, daunorubicin (DNR), adriamycin and paclitaxel in vitro and in vivo (10,15-18), and it has been shown to enhance the effects of interventional therapies for the treatment of hepatocellular carcinoma (19). Curcumin can sensitize tumors to different chemotherapeutic agents by mechanisms that include MDR modulation $(20,21)$. Restoration of drug sensitivity has been achieved by several agents including vitamin $\mathrm{E}$, which has been shown to act as a P-gp inhibitor $(22)$, tetrandrine $(6,23,24)$ and the flavonoid 
quercetin, which is an MDR modulator and thus a potential chemosensitizer (25).

We also found that baker's and brewer's yeast, Saccharomyces cerevisiae, acts as an anticancer agent. This natural product is a commercially available food supplement and a necessary component for the production of fermented foods (such as bread and beer). Its anticancer activity has been evidenced in in vitro studies involving several human cancer cell lines that undergo apoptosis upon the phagocytosis of killed S. cerevisiae. These cancer cells include breast, tongue and colon (26-29). In addition, $S$. cerevisiae can induce apoptosis in nude mice bearing human breast cancer $(30,31)$ and in Swiss albino mice bearing Ehrlich carcinoma (32). Studies have shown that one of the metabolites of yeast, trehalose, exerts anticancer effects when combined with synthetic agents. Such yeast metabolites may represent another mechanism by which yeast exhibits an anticancer effect (33). Furthermore, we have recently shown that $S$. cerevisiae sensitizes different mammary cancer cells to chemotherapy in vitro, with the $\mathrm{IC}_{50}$ value for paclitaxel being significantly reduced against breast cancer cells in the presence of $S$. cerevisiae (34).

In the present study, we evaluate the ability of $S$. cerevisiae to sensitize cancer cells to chemotherapy, paclitaxel, using mice bearing Ehrlich ascites carcinoma (EAC). While our previous study demonstrated yeast's ability to sensitive human and murine breast cancer cells to chemotherapeutic agents in vitro (34), the present study sought to explore whether this in vitro effect is observable in vivo using an EAC mouse model. EAC is a spontaneous murine mammary adenocarcinoma (35) that appeared first as a spontaneous breast cancer in a female mouse and has been commonly used as an experimental tumor by transplanting tumor tissues subcutaneously from mouse to mouse (36). EAC is an undifferentiated carcinoma, is originally hyperdiploid, and has high transplantable capability, rapid proliferation, shorter life span and $100 \%$ malignancy (37). EAC models are frequently utilized by our group and others in the development of antitumorigenic agents $(34,38)$. Results of the present study show that $S$. cerevisiae can sensitize EAC cells in mice to paclitaxel by mechanisms involving induction of apoptosis. In addition, S. cerevisiae combined with paclitaxel at low dose has a more significant anticancer effect than paclitaxel alone at high dose. The present study shows that yeast is a potent chemosensitizer and it may have clinical implications for the treatment of breast cancer.

\section{Materials and methods}

Paclitaxel $\left(\right.$ Taxol $\left.^{\circledR}\right)$. Paclitaxel was purchased from BristolMyers Squibb Inc. (Princeton, NJ, USA). It was supplied with an initial concentration of $100 \mathrm{mg} / 16.7 \mathrm{ml}$. Each $\mathrm{ml}$ of sterile non-pyrogenic solution contains $6 \mathrm{mg}$ paclitaxel, $527 \mathrm{mg}$ of purified Cremophor ${ }^{\circledR}$ EL (polyoxyethylated castor oil) and $49.7 \%$ (vol/vol) dehydrated alcohol, United States Pharmacopeia (USP).

Preparation of S. cerevisiae. Commercially available baker's and brewer's yeast, $S$. cerevisiae, was used in suspensions that were washed once with phosphate-buffered saline (PBS). It was then incubated for $1 \mathrm{~h}$ at $90^{\circ} \mathrm{C}$ to kill the yeast and washed three times with PBS. Quantification was carried out using a hemocytometer, and cell suspensions were adjusted to $1 \times 10^{7}$ cells/ml (34). The yeast was given locally to mice-bearing EAC at $0.1 \mathrm{ml} / \mathrm{mouse}$ three times a week for 25 days starting from day 8 of tumor cell inoculation.

Animals. Eighty female Swiss albino mice (2 months old) weighing 19-21 g were used in the present study. The mice were purchased from the National Cancer Institute, Cairo University, (Cairo, Egypt) and were housed in our animal research facility at constant temperature $\left(24^{\circ} \mathrm{C} \pm 2^{\circ} \mathrm{C}\right) 50^{\circ} \mathrm{F}$ at $10 \%$ relative humidity, and alternating 12 -h light/dark cycles. Mice were accommodated for 1 week prior to experiments. Animals were provided with standard cube pellets and water ad libitum. The diet consists of casein (12.5\%), fats $(1.0 \%)$, wheat flour (80\%), bran (3.3\%), olive oil (2.3\%), DL-methionine $(0.5 \%)$, vitamins and salt mixture $(0.2 \%)$ and water $(0.2 \%)$. The ratio of total calories was $\sim 18 \%$ protein, $73 \%$ carbohydrate and $9 \%$ fat. The pellets were purchased from Misr Oil \& Soap Co. (Cairo, Egypt). The actual food intake was previously monitored and found to be from 4 to $5 \mathrm{~g} /$ day/animal weighing $20 \pm 2 \mathrm{~g}$. Animal protocols were in compliance with the Guide for the Care and Use of Laboratory Animals at the University of Mansoura, Egypt.

Preparation of Ehrlich ascites carcinoma (EAC) cells and tumor transplantation. EAC cells were kindly supplied by the National Cancer Institute, Cairo University, (Cairo, Egypt) and were maintained by weekly intraperitoneal transplantation of $2.5 \times 10^{6}$ cells in female Swiss albino mice. In this experiment, solid tumors were produced by intramuscular injection with $0.2 \mathrm{ml}$ EAC cells $\left(2.5 \times 10^{6}\right.$ cells $)$ in the right thigh of the lower limb of the mice. Viability of the tumor cells was assessed to be $95 \%$ by trypan blue dye exclusion method.

Experimental design. At 8 days post-tumor cell inoculation, mice bearing a solid EAC tumor mass of $\sim 100 \mathrm{~mm}^{3}$ were used in the study. Mice were divided into eight groups $(n=10)$ : i) normal control untreated mice; ii) control mice treated with yeast alone; iii) mice bearing tumors receiving intratumoral (i.t.) injections of PBS (EAC); iv) mice bearing tumors receiving i.t. injections of yeast $\left(1 \times 10^{7}\right.$ cells $\left./ \mathrm{ml}\right)$; v) mice bearing tumors receiving paclitaxel at a high dose (paclitaxel-H) $(10 \mathrm{mg} / \mathrm{kg})$; vi) mice bearing tumors receiving paclitaxel at a low dose (paclitaxel-L) $(2 \mathrm{mg} / \mathrm{kg})$; vii) mice bearing tumors receiving yeast plus paclitaxel-H; and viii) mice bearing tumor receiving yeast plus paclitaxel-L. Mice received paclitaxel and/or yeast 3 days/week commencing on day 8 post EAC cell inoculation until the end of the experiment (day 30). On day 30, animals were anesthetized and sacrificed by cervical dislocation. The tumors were excised and immediately frozen or fixed in $10 \%$ neutral formalin for histopathological examination or in 2.5 glutaraldehyde for electron microscopy.

\section{Evaluation of body weight and tumor weight}

Body weight $(B W)$. Mice were examined for initial, final and net $\mathrm{BWs}$ at day 30 . The net final $\mathrm{BW}=$ final $\mathrm{BW}$ - tumor weight. BW gain was determined as the difference between the initial and the net final BW. 
Tumor weight $(T W)$. On day 30 , the mice were euthanized and the solid tumors were excised for weight (TW/g) determination before freezing.

\section{Flow cytometric analysis}

Cell preparation for flow cytometry. Tumor tissues were excised from EAC-bearing mice under different treatment conditions, cut into pieces, and gently rubbed through fine nylon gauze (40-50 mesh count/cm; HD 140 Zuricher Buteltuch fabrik AG, Zürich, Switzerland). Samples were then washed through the gauze with Tris-ethylenediaminetetraacetic acid (TrisEDTA) buffer at pH 7.5 [3.029 g of 0.1 M Tris-(hydroxymethyl aminomethane), $1.022 \mathrm{~g}$ of $0.07 \mathrm{M} \mathrm{HCl}$ and $0.47 \mathrm{~g}$ of $0.005 \mathrm{M}$ Tris-EDTA]. Cells were suspended in PBS, centrifuged for $5 \mathrm{~min}$ at 200-300 x g, resuspended in sterile PBS (cell density $\sim 1 \times 10^{6}$ cells $/ \mathrm{ml}$ ), and then fixed in $70 \%$ ice-cold ethanol in PBS and stored at $-20^{\circ} \mathrm{C}$ until used.

Analysis of apoptosis, DNA damage and cell proliferation assay. Quantitative detection of apoptosis with cleaved poly(ADP-ribose) polymerase (PARP), DNA damage using phosphorylated $\mathrm{H} 2 \mathrm{AX}(\gamma \mathrm{H} 2 \mathrm{AX}$ form), and cell proliferation by bromodeoxyuridine (BrdU) were simultaneously determined in vivo by multicolor flow cytometric analysis using the Apoptosis, DNA Damage and Cell Proliferation kit specific to incorporated BrdU, $\gamma \mathrm{H} 2 \mathrm{AX}$ and cleaved PARP (BD Pharmingen; BD Biosciences, San Diego CA, USA) following the manufacturer's instructions.

Annexin-V/PI. Annexin $\mathrm{V}$ is a protein that binds to phosphatidylserine (PS) residues which are exposed on cell surfaces of apoptotic, but not normal cells. During apoptosis, the PS groups are exposed to the exterior of the cell membrane. This binding of PS with Annexin V is an established biochemical marker of apoptosis. Induction of apoptosis caused by yeast and paclitaxel in EAC-primary tumors was quantitatively determined through flow cytometry using the Annexin V-conjugated Alexa Fluor 488 Apoptosis Detection kit following the manufacturer's instructions (BD Biosciences).

Flow cytometric analysis of Thelper cells $\left(C D 4^{+}\right)$and T cytotoxic cells $\left(C D 8^{+}\right)$. Flow cytometric analysis (FACS) of $\mathrm{CD}^{+}$ and $\mathrm{CD}^{+} \mathrm{T}$ cells that infiltrated EAC tumors was performed using mouse anti-CD4 ${ }^{+}$FITC (clone GK1.5) and mouse anti-CD8 ${ }^{+}$FITC (clone 53-6.7) (BD Biosciences). Tumor cell suspensions in PBS at a concentration of $1 \times 10^{6}$ cells $/ \mathrm{ml}$ were prepared, centrifuged for $5 \mathrm{~min}$ at 200-300 x g, and the supernatant was discarded. Afterwards the cell pellets were re-suspended in $500 \mu 1$ PBS. Subsequently, $1 \mathrm{ml}$ of suspension was dispensed in a flow cytometric tube. Cells were incubated with $25 \mu \mathrm{l}$ of anti-CD4 ${ }^{+}$or anti-CD8 ${ }^{+}$in the dark for $30 \mathrm{~min}$ at $4^{\circ} \mathrm{C}$. The supernatant was discarded and the cells were washed twice by PBS, pH (7.2). Then, $200 \mu 1$ paraformaldehyde solution was added to each tube, mixed well and maintained in the dark at $4^{\circ} \mathrm{C}$ until FACS analysis following the manufacturer's instructions.

Immunostaining for proliferation marker $\mathrm{Ki}-67 . \mathrm{Ki}-67$ is a cell proliferation marker for tumor progression commonly used as an early predictor in breast cancer. Immunohistochemical staining was performed on formalin-fixed paraffin-embedded tissues. Staining was performed using streptoavidin-biotin method as previously described (39) by using the Histostain-Plus kit (Santa Cruz Biotechnology, Santa Cruz, CA, USA) which contains $10 \%$ non-immune serum, biotinylated secondary antibody and streptoavidin-peroxidase. Immunohistochemical reactivities of $\mathrm{Ki}-67$ expression in the different groups were quantified by image analysis (Immuno Ratio-JPEG2000 virtual slide microscope; Institute of Biomedical Technology, University of Tampere, Tampere, Finland).

Histopathological studies. At 30 days post inoculation, the animals were sacrificed, and the tumor specimens under different treatment conditions were removed and fixed in $10 \%$ neutral buffered formalin for at least $24 \mathrm{~h}$. The tissues were embedded in paraffin using a routine method and then cut into 3-4 $\mu \mathrm{m}$ thickness with a microtome and stained with hematoxylin and eosin (H\&E). The H\&E-stained slides were examined under a light microscope (magnification, $\mathrm{x} 4-\mathrm{x} 40$ ).

Electron microscopy (EM). Small fragments ( $1 \mathrm{~mm}^{3}$ blocks) of tissue were fixed in $2.5 \%$ glutaraldehyde, and then put into sodium cacodylate buffer the night before processing and postfixed with osmium tetroxide. The tissues were then embedded in resin. Semi-thin sections were cut using a glass knife and stained with toluidine blue. Semi-thin sections are required to confirm the presence of desired cells and to select the best tissue block for thin-sectioning. Finally, thin sections were cut on a diamond knife. Routine staining was performed with uranyl acetate followed by lead citrate (40), and examined using JEOL Electron Microscope (JEOL Ltd., Tokyo, Japan) operating at $60 \mathrm{kV}$.

Statistical analysis. Values are reported as mean \pm standard error (SE) and data were analyzed using one-way analysis of variance (ANOVA) followed by least significant difference (LSD) post hoc test for multiple comparisons. $\mathrm{P}<0.05$ was considered to indicate a statistically significant result.

\section{Results}

This study evaluated the chemosensitizing effect of yeast in mice bearing tumor. Parameters under investigation included body weight, tumor weight, cell proliferation, DNA damage, apoptosis in tumor cells, $\mathrm{CD}^{+}$and $\mathrm{CD}^{+} \mathrm{T}$ cells infiltrated in tumor tissue and Ki-67 expression. Histopathology and ultrastructural examinations were also used. In addition, adverse side-effects from the yeast treatment and/or paclitaxel were also monitored.

Changes in the body weight $(B W)$. As shown in Fig. 1, all animal groups showed an increase in BW after one month of treatment, as compared to the initial BW. The percentage of weight gain compared to initial body weight was as follows: i) control untreated mice, $15.5 \%$; ii) yeast-treated control mice, $15.4 \%$; iii) untreated EAC-bearing mice showed only $2.0 \%$; iv) yeast-treated EAC-bearing mice showed $9.3 \%$; v and vi) paclitaxel-treated (high and low doses) EAC-bearing mice showed 9.4 and $7.0 \%$, respectively; and vii and viii) paclitaxel (high and low) combined with yeast was 18 and 


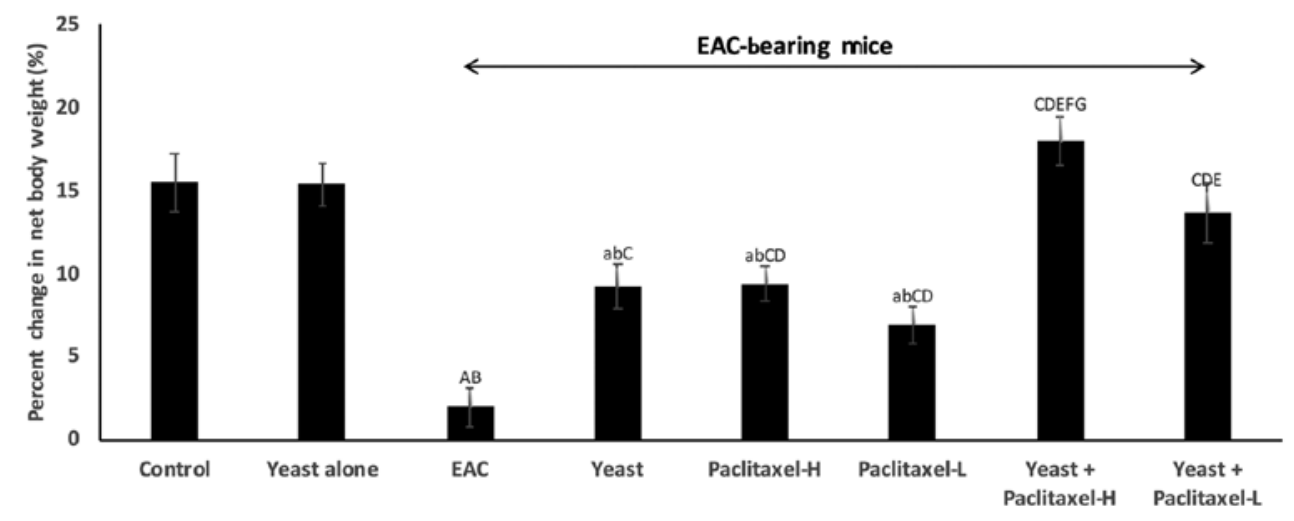

Figure 1. Effect of yeast and/or paclitaxel on body weight change (g). Data are expressed as mean \pm SE of 10 mice/group). ${ }^{\mathrm{a}} \mathrm{P}<0.05$ and ${ }^{\mathrm{A}} \mathrm{P}<0.01$, significantly different from the normal control untreated group. ${ }^{\mathrm{b}} \mathrm{P}<0.05$ and ${ }^{\mathrm{B}} \mathrm{P}<0.01$, significantly different from the control treated with yeast group. ${ }^{\mathrm{C}} \mathrm{P}<0.01$, significantly different from the EAC group. ${ }^{\mathrm{D}} \mathrm{P}<0.01$, significantly different from the yeast-treated EAC group. ${ }^{\mathrm{E}} \mathrm{P}<0.01$, significantly different from the paclitaxel-H-treated EAC group. ${ }^{\mathrm{F}} \mathrm{P}<0.01$, significantly different from the paclitaxel-L-treated EAC group. ${ }^{\mathrm{G}} \mathrm{P}<0.01$, significantly different from the yeast + paclitaxel-H-treated EAC group. Net final body weight $=$ (final body weight - tumor weight). Body weight change $=$ (net final body weight - initial body weight). EAC, Ehrlich ascites carcinoma. Groups: EAC, mice bearing tumors receiving intratumoral (i.t.) injections of PBS; Yeast, mice bearing tumors receiving i.t. injections of yeast $\left(1 \times 10^{7}\right.$ cells $\left./ \mathrm{ml}\right)$; paclitaxel- $\mathrm{H}$, mice bearing tumors receiving paclitaxel at a high dose $(10 \mathrm{mg} / \mathrm{kg})$; paclitaxel- $\mathrm{L}$, mice bearing tumors receiving paclitaxel at a low dose $(2 \mathrm{mg} / \mathrm{kg})$; Yeast + Paclitaxel-H, mice bearing tumors receiving yeast plus paclitaxel-H; Yeast + Paclitaxel-L, mice bearing tumors receiving yeast plus paclitaxel-L.

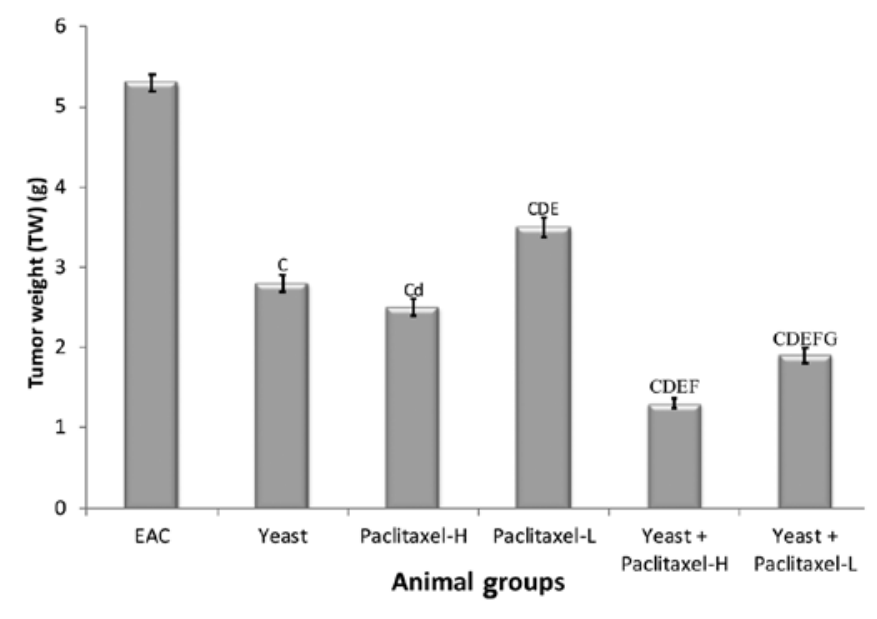

Figure 2. Tumor weight of the EAC mouse-bearing tumors treated with yeast in the presence or absence of paclitaxel. Data are expressed as mean $\pm \mathrm{SE}$ of $10 \mathrm{mice} / \mathrm{group} .{ }^{\mathrm{C}} \mathrm{P}<0.01$, significantly different from the EAC group. ${ }^{\mathrm{d}} \mathrm{P}<0.05$ and ${ }^{\mathrm{D}} \mathrm{P}<0.01$, significantly different from the yeast-treated EAC group. ${ }^{\mathrm{E}} \mathrm{P}<0.01$, significantly different from the paclitaxel-H-treated EAC group. ${ }^{\mathrm{F}} \mathrm{P}<0.01$, significantly different from the paclitaxel-L-treated EAC group. ${ }^{\mathrm{G}} \mathrm{P}<0.01$, significantly different from the yeast + paclitaxel-H-treated EAC group. EAC, Ehrlich ascites carcinoma. Groups: EAC, mice bearing tumors receiving intratumoral (i.t.) injections of PBS; Yeast, mice bearing tumors receiving i.t. injections of yeast $\left(1 \times 10^{7}\right.$ cells $\left./ \mathrm{ml}\right)$; paclitaxel- $\mathrm{H}$, mice bearing tumors receiving paclitaxel at a high dose $(10 \mathrm{mg} / \mathrm{kg})$; paclitaxel-L, mice bearing tumors receiving paclitaxel at a low dose $(2 \mathrm{mg} / \mathrm{kg})$; Yeast + Paclitaxel-H, mice bearing tumors receiving yeast plus paclitaxel-H; Yeast + Paclitaxel-L, mice bearing tumors receiving yeast plus paclitaxel-L.

$13.7 \%$, respectively. The results demonstrated that the combined treatment with yeast and paclitaxel-L showed an increase of $13.7 \%$ in $\mathrm{BW}$, while treatment with paclitaxel-H alone presented an increase of $9.4 \%$.

Animals were monitored to observe potential toxic side effects of yeast treatment. Injections (i.t.) of S. cerevisiae alone or in the presence of paclitaxel showed no adverse side-effects as indicated by normality of feeding/drinking and life activity patterns for the entire treatment period.
Changes in tumor weight $(T W)$. The percent change in TW on day 30 in the different groups, as compared to EAC-bearing mice $(5.3 \pm 0.11 \mathrm{~g})$ was examined. Data depicted in Fig. 2 show significant suppressive effects on TW by individual treatments, including the following: yeast alone $-46.8 \%$, paclitaxel- $\mathrm{H}$ alone $-52.6 \%$ and paclitaxel-L alone $-33.6 \%$; and combined treatments with yeast plus paclitaxel-H and yeast plus paclitaxel-L showed -75.1 and $-63.7 \%$, respectively. Results of this study revealed that combined treatment with yeast and paclitaxel-L showed a more significant decrease in TW (63.7\%) than that caused by paclitaxel-H alone $(-52.6 \%)$. Similar trends were observed in the last tumor volume (data not shown).

\section{Flow cytometric analysis of cell proliferation, DNA damage} and apoptosis of EAC

Determination of cell proliferation. Fig. 3 shows the suppressive effect of yeast and/or paclitaxel on the percentage of tumor cell proliferation as compared to EAC: treatment with yeast alone showed $-45 \%(\mathrm{P}<0.01)$; treatment with paclitaxel$\mathrm{L}$ alone and paclitaxel-H alone was $-35 \%(\mathrm{P}<0.05)$ and $-42 \%$ $(\mathrm{P}<0.01)$, respectively; and combined treatments with yeast plus paclitaxel-L and yeast plus paclitaxel-H showed -56 and $-68 \%$ $(\mathrm{P}<0.01)$, respectively. Thus, it appears that the combined treatment with yeast and paclitaxel-L resulted in a larger decrease in cell proliferation as compared to paclitaxel- $\mathrm{H}$ alone.

Determination of DNA damage. As shown in Fig. 3, individual treatments of yeast, paclitaxel-L and paclitaxel-H caused significant increase in the percent change in DNA damage. In addition, combined treatments with yeast plus paclitaxel-L and yeast plus paclitaxel-H showed even greater damage. Again, it appears that the combined treatment with yeast and paclitaxel-L resulted in a greater increase in DNA damage as compared to paclitaxel-H alone.

Determination of apoptosis. Data in Fig. 3 showed that the individual treatments of yeast, paclitaxel-L and paclitaxel- $\mathrm{H}$ caused a significant increase in tumor cell apoptosis. In addi- 


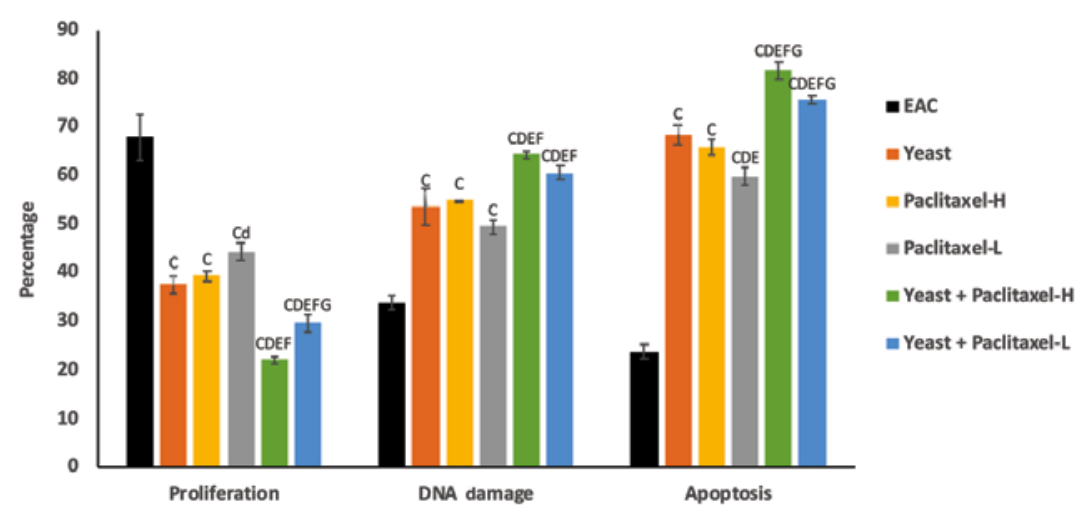

Figure 3. Effect of yeast and/or paclitaxel on the percentage of cell proliferation, DNA damage and apoptosis in tumor tissues of the different groups. Data are expressed as mean $\pm \mathrm{SE}\left(5\right.$ mice/group). ${ }^{\mathrm{C}} \mathrm{P}<0.01$, significantly different from the EAC group. ${ }^{\mathrm{d}} \mathrm{P}<0.05$ and ${ }^{\mathrm{D}} \mathrm{P}<0.01$, significantly different from the yeasttreated EAC group. ${ }^{\mathrm{E}} \mathrm{P}<0.01$, significantly different from the paclitaxel-H-treated EAC group. ${ }^{\mathrm{F}} \mathrm{P}<0.01$, significantly different from the paclitaxel-- treated EAC group. ${ }^{\mathrm{G}} \mathrm{P}<0.01$, significantly different from the yeast + paclitaxel-H-treated EAC group. EAC, Ehrlich ascites carcinoma. Groups: EAC, mice bearing tumors receiving intratumoral (i.t.) injections of PBS; Yeast, mice bearing tumors receiving i.t. injections of yeast $\left(1 \mathrm{x} 10^{7} \mathrm{cell} / \mathrm{s} / \mathrm{ml}\right)$; paclitaxel-H, mice bearing tumors receiving paclitaxel at a high dose $(10 \mathrm{mg} / \mathrm{kg})$; paclitaxel-L, mice bearing tumors receiving paclitaxel at a low dose $(2 \mathrm{mg} / \mathrm{kg})$; Yeast $+\mathrm{Paclitaxel}-\mathrm{H}$, mice bearing tumors receiving yeast plus paclitaxel-H; Yeast + Paclitaxel-L, mice bearing tumors receiving yeast plus paclitaxel-L.

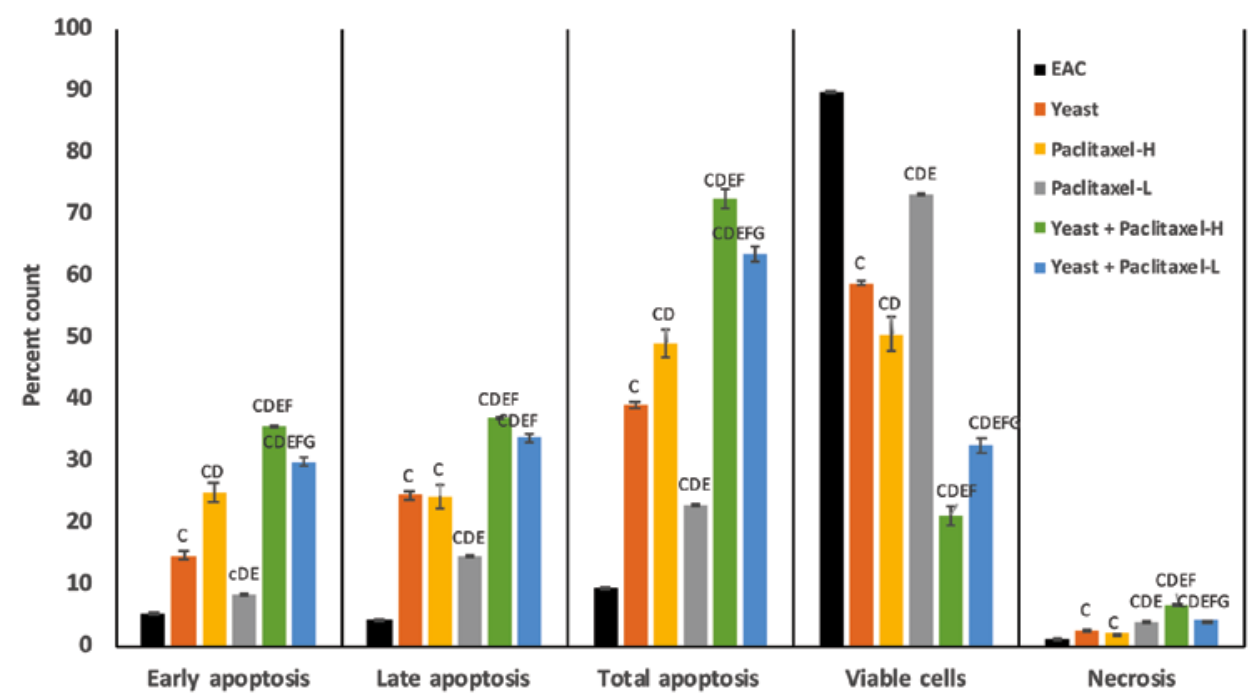

Figure 4. Effect of paclitaxel and/or yeast treatment on the Annexin V/PI labeling in tumor tissues of the different groups. Data are expressed as mean \pm SE (5 mice/group). ${ }^{\mathrm{C}} \mathrm{P}<0.05$ and ${ }^{\mathrm{C}} \mathrm{P}<0.01$, significantly different from the $\mathrm{EAC}$ group. ${ }^{\mathrm{D}} \mathrm{P}<0.01$, significantly different from the yeast-treated EAC group. ${ }^{\mathrm{E}} \mathrm{P}<0.01$, significantly different from the paclitaxel-H-treated EAC group. ${ }^{\mathrm{F}} \mathrm{P}<0.01$, significantly different from the paclitaxel-L-treated EAC group. ${ }^{\mathrm{G}} \mathrm{P}<0.01$, significantly different from the yeast + paclitaxel-H-treated EAC group. EAC, Ehrlich ascites carcinoma. Groups: EAC, mice bearing tumors receiving intratumoral (i.t.) injections of PBS; Yeast, mice bearing tumors receiving i.t. injections of yeast $\left(1 \times 10^{7}\right.$ cells $\left./ \mathrm{ml}\right)$; paclitaxel- $\mathrm{H}$, mice bearing tumors receiving paclitaxel at a high dose $(10 \mathrm{mg} / \mathrm{kg})$; paclitaxel-L, mice bearing tumors receiving paclitaxel at a low dose $(2 \mathrm{mg} / \mathrm{kg})$; Yeast + Paclitaxel-H, mice bearing tumors receiving yeast plus paclitaxel-H; Yeast + Paclitaxel-L, mice bearing tumors receiving yeast plus paclitaxel-L.

tion, combined treatments with yeast plus paclitaxel- $\mathrm{L}$ and yeast plus paclitaxel-H showed higher increase in tumor cell apoptosis. Results again showed that treatment with yeast plus paclitaxel- $\mathrm{L}$ resulted in a larger increase in apoptosis as compared to paclitaxel-H alone.

Quantitative determination of apoptosis by Annexin V/PI double staining. A quantitative analysis of apoptosis in tumor cells induced by yeast and/or paclitaxel was performed by flow cytometry using Annexin V/PI double staining. Fig. 4 summarizes the results of early, late and total apoptosis post-treatment with yeast in the presence and absence of paclitaxel. The percent change in early apoptotic cell count in the different groups, as compared to the control untreated EAC-bearing mice, was as follows: treatment of yeast alone showed 179\%; treatment with paclitaxel-L alone and paclitaxel-H alone was $60 \%(\mathrm{P}<0.01)$ and $326 \%(\mathrm{P}<0.01)$, respectively; and treatment with yeast plus paclitaxel-L and yeast plus paclitaxel-H showed 471 and 582\% $(\mathrm{P}<0.01)$, respectively. Combined treatment with yeast and paclitaxel-L resulted in an increase of $471 \%$ in early apoptosis, as compared to the $326 \%$ increase achieved by a paclitaxel-H alone. A similar trend of results was noted in the percent change in late and total apoptotic cell count in the different groups as compared to control untreated EAC-bearing mice.

Furthermore, data in Fig. 4 shows the percentage of viable tumor cells in mice under different treatment conditions as compared to control untreated EAC-bearing mice. Mice 
Table I. Immunohistochemical examination of the inhibitory effect of yeast and or paclitaxel on the percentage of proliferation of EAC tumor cells in the different groups using the Ki-67 marker.

\begin{tabular}{lcc}
\hline Groups & Mean \pm SE & $\%$ of change from EAC \\
\hline EAC & $18.2 \pm 0.17$ & - \\
Yeast & $9.1 \pm 0.31^{\mathrm{a}}$ & 50 \\
Paclitaxel-H & $10.9 \pm 0.09^{\mathrm{a}}$ & 40 \\
Paclitaxel-L & $11.6 \pm 0.26^{\mathrm{a}}$ & 36 \\
Yeast + Paclitaxel-H & $0.7 \pm 0.058^{\mathrm{a}}$ & 96 \\
Yeast + Paclitaxel-L & $0.9 \pm 0.053^{\mathrm{a}}$ & 95 \\
\hline
\end{tabular}

Data are expressed as mean $\pm \mathrm{SE}$ of 5 mice/group. ${ }^{\mathrm{a}} \mathrm{P}<0.01$, significant difference compared to the untreated control group. EAC, Ehrlich ascites carcinoma. Groups: EAC, mice bearing tumors receiving intratumoral (i.t.) injections of PBS; Yeast, mice bearing tumors receiving i.t. injections of yeast $\left(1 \times 10^{7}\right.$ cells $\left./ \mathrm{ml}\right)$; paclitaxel- $\mathrm{H}$, mice bearing tumors receiving paclitaxel at a high dose $(10 \mathrm{mg} / \mathrm{kg})$; paclitaxel-L, mice bearing tumors receiving paclitaxel at a low dose $(2 \mathrm{mg} / \mathrm{kg})$; Yeast + Paclitaxel-H, mice bearing tumors receiving yeast plus paclitaxel-H; Yeast + Paclitaxel-L, mice bearing tumors receiving yeast plus paclitaxel-L.

treated with a combination of yeast and paclitaxel-L resulted in a decrease in the percentage of viable tumor cells by $-64 \%$ $(\mathrm{P}<0.01)$ while paclitaxel-H alone showed a decrease of $-44 \%$ $(\mathrm{P}<0.01)$. In addition, the percent change in necrotic cells showed that combined treatment with yeast and paclitaxel$\mathrm{L}$ resulted in an increase of $323 \%(\mathrm{P}<0.01)$ in tumor cell necrosis, as compared to a $110 \%(\mathrm{P}<0.01)$ increase achieved by paclitaxel-H alone.

Evaluation of Ki-67 cell proliferation marker. Cell proliferation in EAC cells treated with yeast with or without paclitaxel was determined by Ki-67 marker immunohistochemical staining (Table I). Control untreated EAC bearing mice showed an increase in Ki-67-positive nuclei of the neoplastic cells. The percent decrease in cell proliferation in the different groups, as compared to the EAC-bearing mice, was as follows: treatment of yeast alone showed $50 \%$, EAC-bearing animals treated with paclitaxel-H alone and paclitaxel-L alone was $40 \%(\mathrm{P}<0.01)$ and $36 \%(\mathrm{P}<0.01)$, respectively; and animals treated with yeast plus paclitaxel-H and yeast plus paclitaxel-L showed 96 and 95\% $(\mathrm{P}<0.01)$, respectively.

Detection of $\mathrm{CD}^{+}$and $C D 8^{+} T$ cells infiltrating the tumor by flow cytometric analysis

Infiltrated $C D 4^{+}$T cells. Table II shows that the percent increase in infiltrated $\mathrm{CD}^{+} \mathrm{T}$ cells in the different groups, as compared to EAC-bearing mice, is as follows: treatment of yeast alone $57 \%$, paclitaxel-H alone $49 \%$ and paclitaxel-L alone $38 \%$. In addition animals treated with yeast plus paclitaxel- $\mathrm{H}$ and yeast plus paclitaxel-L showed 72 and 54\%, respectively.

Infiltrated $C D 8^{+} T$ cells. Table II also shows that the percent increase in infiltrated $\mathrm{CD}^{+} \mathrm{T}$ cells in the different groups, as
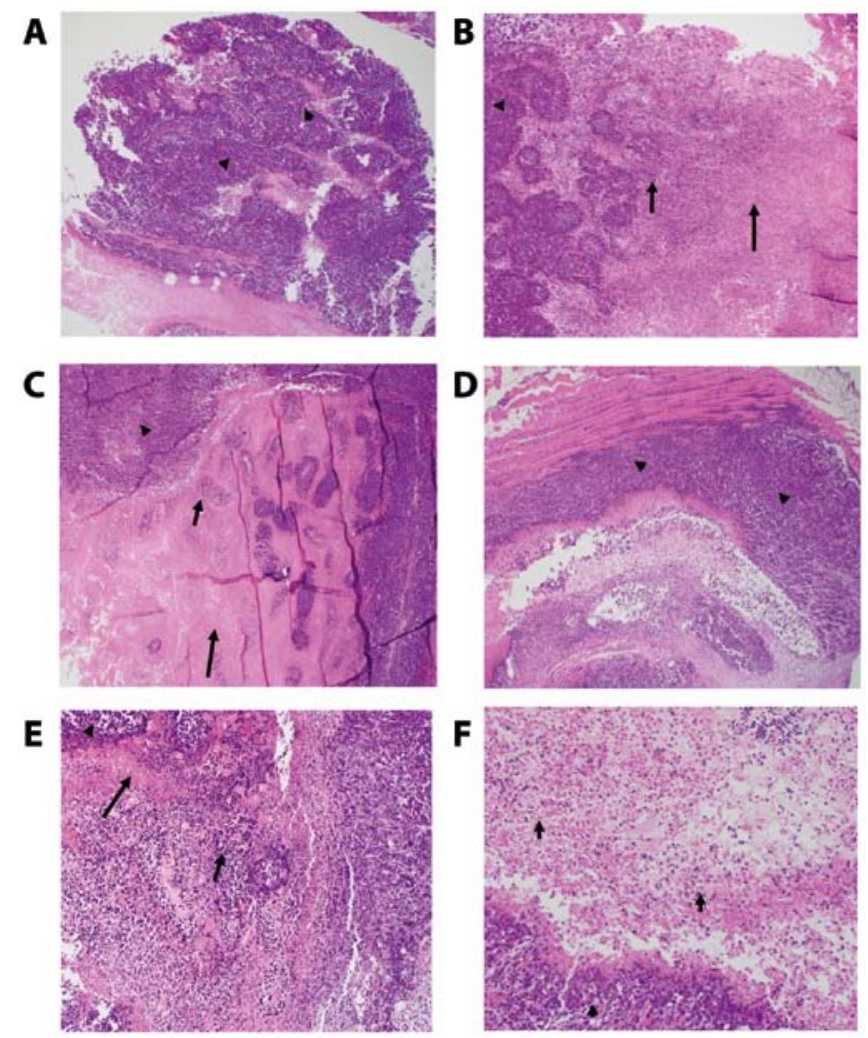

Figure 5. (A-F) Photomicrographs of the mouse-bearing Ehrlich ascites carcinoma (EAC) tumor tissues. (A) Control untreated. Sheets of pleomorphic tumor cells (arrow head) (x4). (B) Yeast treated. Tumor (arrow head)/ colliquative (middle arrow)/coagulative (right arrow) necrosis (x10). (C) Paclitaxel-H. Tumor (arrow head)/colliquative (middle arrow)/coagulative (tall arrow) necrosis (x10). (D) Paclitaxel-L. Sheets of pleomorphic tumor cells (arrow head) (x4). (E) Yeast + Paclitaxel-H. Tumor (arrow head)/colliquative (middle arrow)/coagulative (tall arrow) necrosis (x10). (F) Yeast + Paclitaxel-L. Tumor (arrow head), Colliquative necrosis (x10).

compared to EAC-bearing mice, is as follows: treatment of yeast alone showed $75 \%$, paclitaxel-H alone $41 \%$ and paclitaxel-L alone $15 \%$. Data also showed that animals treated with yeast plus paclitaxel-H and yeast plus paclitaxel-L showed 93 and $62 \%$, respectively.

Histopathology of tumor tissues. We examined H\&E staining of the solid tumors removed from the EAC-bearing mice under different treatment conditions using light microscopy. The different groups include the control untreated EAC-bearing mice (A), EAC-bearing mice injected with yeast (B), EAC-bearing mice treated with paclitaxel-H (C), EAC-bearing mice treated with paclitaxel-L (D), EAC-bearing mice treated with yeast plus paclitaxel-H (E), and EAC-bearing mice treated with yeast plus paclitaxel-L $(\mathrm{F})$. Results of the treatments are illustrated in Table III and Fig. 5A-F.

H\&E-stained sections of the tumor in all groups (Fig. 5A-F) showed poorly differentiated invasive carcinoma. The neoplastic cells were large, had a high $\mathrm{N}: \mathrm{C}$ ratio and exhibited markedly pleomorphic nuclei. Many mitoses including abnormal forms were noted. All tissue sections of the tumor in all groups displayed tumor necrosis that mostly occurred at the center of the tumor nodule. The necrotic tumor appeared acellular, stained homogenously with red eosin, retained the general architectural pattern of the tissue and was 
Table II. Effect of yeast and/or paclitaxel treatment on T-helper lymphocytes $\left(\mathrm{CD} 4^{+}\right)$infiltrated and cytotoxic lymphocytes $\left(\mathrm{CD}^{+}\right)$infiltrated in tumor tissue.

Parameters

\begin{tabular}{|c|c|c|c|c|}
\hline \multirow[b]{2}{*}{ Groups } & \\
\hline & $\% \mathrm{CD}^{+} \mathrm{T}$ cells & $\%$ change from EAC group & $\% \mathrm{CD}^{+} \mathrm{T}$ cells & $\%$ change from EAC group \\
\hline EAC & $28.11 \pm 0.27$ & & $11.48 \pm 0.45$ & \\
\hline Yeast & $44.10 \pm 1.4^{\mathrm{C}}$ & 56.9 & $20.05 \pm 0.29^{C}$ & 74.6 \\
\hline Paclitaxel-H & $41.76 \pm 0.45^{\mathrm{C}}$ & 48.6 & $16.17 \pm 0.66^{\mathrm{C}, \mathrm{D}}$ & 40.8 \\
\hline Paclitaxel-L & $38.76 \pm 1.1^{\mathrm{C}, \mathrm{D}, \mathrm{e}}$ & 37.9 & $13.18 \pm 0.39^{\mathrm{D}, \mathrm{E}}$ & 14.8 \\
\hline Yeast + Paclitaxel-H & $48.35 \pm 0.76^{\mathrm{C}, \mathrm{E}, \mathrm{F}}$ & 72.0 & $22.20 \pm 0.36^{\mathrm{C}, \mathrm{d}, \mathrm{E}, \mathrm{F}}$ & 93.3 \\
\hline Yeast + Paclitaxel-L & $43.16 \pm 0.97^{\mathrm{C}, \mathrm{F}, \mathrm{G}}$ & 53.6 & $18.55 \pm 0.92^{\mathrm{C}, \mathrm{D}, \mathrm{e}, \mathrm{F}, \mathrm{G}}$ & 61.5 \\
\hline
\end{tabular}

Data are expressed as mean \pm SE of 5 mice/group. ${ }^{\mathrm{C}} \mathrm{P}<0.01$, significantly different from the EAC group. ${ }^{\mathrm{d}} \mathrm{P}<0.05$ and ${ }^{\mathrm{D}} \mathrm{P}<0.01$, significantly different from the yeast-treated EAC group. ${ }^{\mathrm{e}} \mathrm{P}<0.05$ and ${ }^{\mathrm{E}} \mathrm{P}<0.01$, significantly different from the paclitaxel-H-treated EAC group. ${ }^{\mathrm{F}} \mathrm{P}<0.01$, significantly different from the paclitaxel-L-treated EAC group. ${ }^{\mathrm{G}} \mathrm{P}<0.01$, significantly different from the yeast + paclitaxel-H-treated EAC group. EAC, Ehrlich ascites carcinoma. Groups: EAC, mice bearing tumors receiving intratumoral (i.t.) injections of PBS; Yeast, mice bearing tumors receiving intratumoral (i.t.) injections of yeast $\left(1 \times 10^{7}\right.$ cells $\left./ \mathrm{ml}\right)$; paclitaxel-H, mice bearing tumors receiving paclitaxel at a high dose $(10 \mathrm{mg} / \mathrm{kg})$; paclitaxel-L, mice bearing tumors receiving paclitaxel at a low dose $(2 \mathrm{mg} / \mathrm{kg})$; Yeast + Paclitaxel- $\mathrm{H}$, mice bearing tumors receiving yeast plus paclitaxel-H; Yeast + Paclitaxel-L, mice bearing tumors receiving yeast plus paclitaxel-L.

Table III. Histopathological analysis of the tumors from mice under the different treatment conditions.

\begin{tabular}{|c|c|c|c|c|c|c|}
\hline \multirow[b]{2}{*}{ Parameters } & \multicolumn{6}{|c|}{ Treatments } \\
\hline & $\begin{array}{l}\text { EAC } \\
(\mathrm{A})\end{array}$ & $\begin{array}{l}\text { Yeast } \\
\text { (B) }\end{array}$ & $\begin{array}{l}\text { Paclitaxel-H } \\
\text { (C) }\end{array}$ & $\begin{array}{l}\text { Paclitaxel-L } \\
\text { (D) }\end{array}$ & $\begin{array}{c}\text { Yeast }+ \text { Paclitaxel-H } \\
(\mathrm{E})\end{array}$ & $\begin{array}{c}\text { Yeast }+ \text { Paclitaxel-L } \\
(\mathrm{F})\end{array}$ \\
\hline $\begin{array}{l}\text { Sheets of highly } \\
\text { undifferentiated } \\
\text { pleomorphic cells, } \%\end{array}$ & $65 \%$ & $50 \%$ & $30 \%$ & $60 \%$ & $30 \%$ & $30 \%$ \\
\hline Extent of necrosis & $35 \%$ & $50 \%$ & $70 \%$ & $40 \%$ & $70 \%$ & $70 \%$ \\
\hline $\begin{array}{l}\text { a. Extent of coagulative } \\
\text { necrosis, } \%\end{array}$ & $30 \%$ & $40 \%$ & $60 \%$ & $20 \%$ & $40 \%$ & $50 \%$ \\
\hline $\begin{array}{l}\text { b. Extent of colliquative } \\
\text { necrosis, } \%\end{array}$ & $5 \%$ & $10 \%$ & $10 \%$ & $20 \%$ & $30 \%$ & $20 \%$ \\
\hline $\begin{array}{l}\text { Total number of } \\
\text { bizarre/multinucleated } \\
\text { cells among the total number } \\
\text { of HPFs per slide }\end{array}$ & $55 / 5=11$ & $66 / 22=3$ & $392 / 49=8$ & $408 / 68=6$ & $255 / 51=5$ & $244 / 61=4$ \\
\hline $\begin{array}{l}\text { Total number of mitoses } \\
\text { per slide in high power } \\
\text { fields (HPF or } x 40 \text { ) }\end{array}$ & $52 / 14=3.7$ & $51 / 29=1.8$ & $152 / 49=3.1$ & $244 / 74=3.3$ & $169 / 51=3.3$ & $108 / 61=1.8$ \\
\hline $\begin{array}{l}\text { Average number of } \\
\text { mitoses per HPF }\end{array}$ & 4 & 2 & 3 & 3 & 3 & 2 \\
\hline
\end{tabular}

High power field $(\mathrm{HPF})$ magnification $=\mathrm{x} 40$ plus the eyepiece magnification of $\mathrm{x} 10$ is $\mathrm{x} 400$ magnification. EAC, Ehrlich ascites carcinoma. Groups: EAC, mice bearing tumors receiving intratumoral (i.t.) injections of PBS; Yeast, mice bearing tumors receiving intratumoral (i.t.) injections of yeast $\left(1 \times 10^{7}\right.$ cells $\left./ \mathrm{ml}\right)$; paclitaxel-H, mice bearing tumors receiving paclitaxel at a high dose $(10 \mathrm{mg} / \mathrm{kg})$; paclitaxel-L, mice bearing tumors receiving paclitaxel at a low dose $(2 \mathrm{mg} / \mathrm{kg})$; Yeast + Paclitaxel-H, mice bearing tumors receiving yeast plus paclitaxel-H; Yeast + Paclitaxel-L, mice bearing tumors receiving yeast plus paclitaxel-L. (A-F refer to images in Fig. 5).

found to be characterized by abrupt transition from viable to necrotic tissue (coagulative necrosis). This necrotic area was marginated by degenerated tumor cells and inflammatory cells (colliquative necrosis).
The effects of the different treatments were evaluated via testing the following parameters: size of the tumor, extent of necrosis, number of bizarre/multinucleated tumor cells, and the degree of proliferative activity of the tumor (number of 

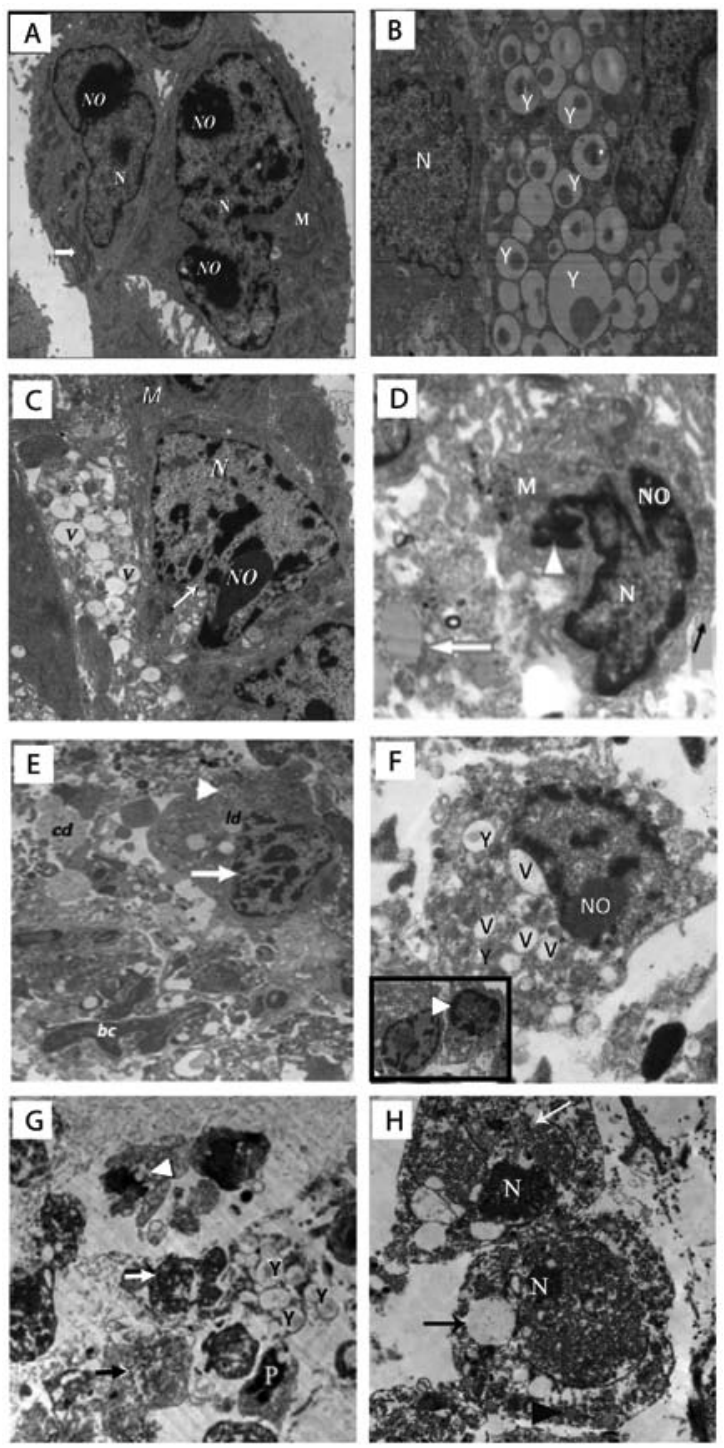

Figure 6. (A-H) Electron micrographs of tumor tissues from the Ehrlich ascites carcinoma (EAC)-bearing mice under different treatments (A) Untreated tumor tissues showing neoplastic cells with large nucleus or binucleated $(\mathrm{N})$ with defined nucleolus $(\mathrm{NO})$, mitochondria $(\mathrm{M})$, and prominent RER (white arrow) (x3,000). (B and C) Yeast-treated group. (B) Image showing neoplastic cells engulfing massive amounts of yeast (Y). (C) Image showing tumor cells with severe vacuolations (V), and segregation and condensation of chromatin (x2,500). (D) Paclitaxel-H-treated group showing condensation of chromatin (arrowhead) and around the nuclear membrane, cell membrane blebbing (black arrow), vacuolation, and muscle fiber (white arrow) (x4,000). (E) Paclitaxel-L-treated group showing apoptotic cell (arrow head), condensation of chromatin and identification of nucleus (white arrow), cellular debris (cd), phagosome (white arrowhead), lipid droplets (ld), and blood capillary (bc) $(1,500)$. (F) Yeast + paclitaxel-H-treated group showing neoplastic cells engulfing yeast inside them $(\mathrm{Y})$ and extensive vacuolation (V); the inset image shows two apoptotic cells with fragmented nucleus and condensation of chromatin material around the nuclear membrane (arrow head) (x4,000). ( $\mathrm{G}$ and $\mathrm{H}$ ) Yeast + paclitaxel-L-treated group. (G) Image showing apoptotic neoplastic cells (white arrow) with multiple yeasts (Y), apoptotic cell $(\mathrm{P})$, extensive cytoplasmic vacuolation (black arrow) and marked loss of mitochondria (arrow head). (H) Image showing two neoplastic cells with predominance of heterochromatin in their nuclei $(\mathrm{N})$, disruption in the nuclear membrane (white arrow) and large electron lucent cytoplasmic vacuoles (black arrow) (magnification, x1,500 for $\mathrm{G}$ and x 2,000 for $\mathrm{H}$ ). Scale bar, $500 \mathrm{~nm}$. Groups: EAC, mice bearing tumors receiving intratumoral (i.t.) injections of PBS; Yeast, mice bearing tumors receiving intratumoral (i.t.) injections of yeast $\left(1 \times 10^{7}\right.$ cells $\left./ \mathrm{ml}\right)$; paclitaxel- $\mathrm{H}$, mice bearing tumors receiving paclitaxel at a high dose $(10 \mathrm{mg} / \mathrm{kg})$; paclitaxel-L, mice bearing tumors receiving paclitaxel at a low dose $(2 \mathrm{mg} / \mathrm{kg})$; Yeast + Paclitaxel- $\mathrm{H}$, mice bearing tumors receiving yeast plus paclitaxel-H; Yeast + Paclitaxel-L, mice bearing tumors receiving yeast plus paclitaxel-L mitoses). Group A, the control untreated tumor, was used to compare all the other groups. Injecting yeast to the tumor (B) caused an appreciable tumor necrosis as compared with group A. Tumor necrosis was found to be highest and comparable between groups paclitaxel-high (C), yeast + paclitaxel-high (E) and yeast + paclitaxel-low (F). The amount of tumor necrosis in paclitaxel-low (D) was almost comparable with the control group (A). The tumor aggressiveness decreased in all treated groups (B-F) but was least in groups B and $\mathrm{F}$ as evidenced by the lowest number of bizarre tumor cells and the number of mitoses.

In summary, histopathological examination revealed that the addition of yeast to low dose paclitaxel (group F) caused the greatest tumor necrosis and exhibited the least aggressive features (the lowest number of bizarre tumor cells and the lowest proliferative activity).

Ultrastructural observations of tumor tissues. The ultrastructural examination of the tumor samples excised from EAC-bearing mice treated with yeast in the absence or presence of paclitaxel is illustrated in Fig. 6A-H. (A) Control untreated EAC-bearing mice showed tumor cells with large nucleus or binucleated with scattered clumps of heterochromatin across the nucleoplasm and condensed around the nuclear membrane. Cells also displayed scant rough endoplasmic reticulum (RER) and mitochondria (M). (B and C) Treatment with yeast alone showed neoplastic cells engulfing countless numbers of yeast (B). This triggered apoptosis of cancer cells, as indicated by fragmented and condensed chromatin inside nuclei, extensive vacuolation (V), and marked loss of mitochondria (M) and RER (C). (D) Mice treated with paclitaxel-H alone showed highly degenerated apoptotic cancer cells with chromatin condensation and aggregation around the nuclear envelope, extensive vacuolation, destroyed RER, damaged mitochondria and numerous cytoplasmic debris. (E) Tumor tissues treated with paclitaxel-L alone showed apoptotic cancer cells with marginated or degraded chromatin materials in the nucleus, and the cytoplasm contained plenty of electron-dense grainy free ribosomes. (F) Mice treated with yeast plus paclitaxel-H showed apoptotic cancer cells with condensation of chromatin material that were marginated around the nuclear membrane, membrane blebbing, yeast, extensive vacuolation, an increase in the degenerative area with cellular debris, fibrous tissue and marked increase in RER degeneration and mitochondrial destruction. ( $\mathrm{G}$ and $\mathrm{H}$ ) Yeast plus paclitaxel-L group, showing apoptotic cells with fragmented nuclei, several yeast uptaken by the cell, extensive vacuolation, and necrosis. An increase in cellular debris and fibers in the inter-neoplastic stroma, phagosomes and mitochondria with destructed cristae and electron lucent matrix were observed.

\section{Discussion}

Paclitaxel is a frequently used chemotherapeutic agent that was originally isolated from the bark of the Pacific yew tree and was approved in 1994 by the US Food and Drug Administration (FDA) as Taxol ${ }^{\circledR}$ for the treatment of patients with metastatic breast cancer. In addition, paclitaxel exhibits a broad spectrum of activity against other human cancers, such as ovarian, non-small cell lung cancers and malignant brain tumors (41). 
Although paclitaxel induces apoptotic effects on cancer cells at high concentrations (42-45), its treatment is associated with severe side-effects, including myelosuppression, peripheral neuropathy, hypersensitivity reactions, alopecia and cardiac disturbances and gastrointestinal toxicity $(1-3,46)$. Therefore, our research focused on finding dietary agents that may have the ability to reduce the toxicity of chemotherapy by lowering the concentration of drug administered to animals and patients while maintaining potency against cancer cells. Our previous research revealed that arabinoxylan rice bran, Biobran/MGN-3, has the ability to sensitize cancer cells to paclitaxel in animalbearing tumors (47). In addition, Biobran/MGN-3 was found to sensitize hepatocellular carcinoma to chemotherapy and other interventional therapies in a 3-year randomized clinical trial (19). We recently investigated the ability of another dietary agent, baker's and brewer's yeast, $S$. cerevisiae, to sensitize metastatic and non-metastatic breast cancer cells to paclitaxel in vitro and showed the $\mathrm{IC}_{50}$ value for paclitaxel was significantly reduced in the presence of yeast (34).

In the present study, we evaluated the ability of baker's yeast to sensitize cancer cells to paclitaxel in mice bearing EAC. Here, we present evidence showing the ability of baker's yeast to act as a chemosensitizer when used in combination with paclitaxel. Co-treatment of yeast plus paclitaxel at a low dose $(2 \mathrm{mg} / \mathrm{kg} \mathrm{BW}$, paclitaxel-L) resulted in greater anticancer effects than paclitaxel at a high dose $(10 \mathrm{mg} / \mathrm{kg} \mathrm{BW}$, paclitaxel-H) alone. This is clearly evidenced by a greater retardation of tumor growth, greater increase in DNA damage and apoptosis and larger decrease in cell proliferation as compared to paclitaxel-H alone. In addition, histopathological examination confirmed that yeast plus paclitaxel-L produced antitumor effects better than paclitaxel-H alone. Thus, baker's yeast may be used in conjunction with chemotherapy at low concentrations to achieve the same potency as high-dose chemotherapy against cancer cells in mice-bearing EAC.

Apoptosis is an important factor underlying the anticancer effects by yeast and paclitaxel. Our previous studies demonstrated that heat-killed baker's yeast is a potent inducer of apoptosis. This is based on the phenomenon that phagocytosis of yeast by cancer cells triggers apoptosis of cancer cells. Several in vitro studies have demonstrated that human cancer cells can phagocytize yeast, and subsequently these cancer cells showed morphological signs of apoptosis such as nuclear fragmentation and membrane blebbing, in addition, flow cytometric analysis showed mitochondrial polarization and increased activation of caspases-8, -9 and -3 in the BCC post culture with yeast $(26,27,29)$. Furthermore, the current ultra-structural analysis showed neoplastic cells engulfing countless numbers of yeast, which triggered the apoptosis of cancer cells as indicated by fragmented and condensed chromatin inside nuclei and extensive vacuolized cytoplasm. This yeast-induced apoptosis of tumor cells ultimately resulted in significant retardation of tumor growth. These results are in accordance with our previous studies that showed yeast i.t. injection suppressed the growth of mice-bearing EAC tumors (32) and nude mice-bearing human MCF-7 tumor cells. In these studies, treatments with yeast showed active involvement of lysosomes in the phagocytosis and digestion of yeast and in cancer cell apoptosis (31). Further studies showed that yeast-induced apoptosis of human MBC cells occurs by a mechanism involving intracellular $\mathrm{Ca}^{2}$ that may trigger apoptotic signals directly via intrinsic pathway of apoptosis (48).

As a member of the taxane family, paclitaxel suppresses spindle microtubule dynamics. Inhibition of microtubules results in the blockage of metaphase-anaphase transitions, ultimately suppressing cell proliferation by inhibition of mitosis $(49,50)$. In the present study, treatment with paclitaxel inhibited cell proliferation and induced DNA damage in mice-bearing EAC tumors in a dose-dependent manner. Our research and that of others showed that paclitaxel induces apoptosis in a variety of cancer cells including BCCs by both intrinsic and extrinsic pathways of apoptosis, involving modification of mitochondrial membrane potential (MMP) and activation of caspase- 8 and caspase-3 (51-55). Ultra-structural examination showed that treatment with paclitaxel induced cancer cell apoptosis that was associated with chromatin condensation and aggregation around the nuclear envelope and the cytoplasm contained numerous electron-dense grainy free ribosomes. The apoptotic effect by paclitaxel is attributed to the ability of this agent to arrest mitosis through microtubule stabilization.

In the present study, the ability of yeast to sensitize EAC to paclitaxel was well illustrated. Fig. 3 shows that cotreatment of yeast plus paclitaxel-L caused a greater decrease in cell proliferation than paclitaxel-H alone (-56 vs. $-42 \%)$, as examined by BrdU staining and weak expression of KI-67 (a marker of cell proliferation) (95 vs. $40 \%$ ), elevated DNA damage (+79 vs. $+62 \%$ ), and an enhancement of the apoptotic tumor cells $(+217$ vs. $+177 \%)$. These results are in accord with our recent in vitro studies that showed that baker's yeast in the presence of paclitaxel increased the sensitivity of three human and murine BCC lines to paclitaxel (34).

Several dietary products have shown the ability to modulate multi-drug resistance (MDR) and thus have potential as chemosensitizers. For example, the flavonoid quercetin is an MDR modulator (25), curcumin sensitizes cervical cancer cells to cisplatin by suppressing MRP1 and Pgp1 (56) and vitamin E acts as a P-gp inhibitor (22). Dietary fatty acids also act as chemosensitizers by increasing the intracellular chemotherapy drug accumulation in cancer cells $(57,58)$, and tetrandrine is likewise able to restore drug sensitivity $(6,23,24)$. Flow cytometry results from the present study showed yeast to be a chemosensitizer that possesses potential for adjuvant therapy in the treatment of cancer, as exemplified by the fact that yeast in the presence of paclitaxel-L enhances apoptosis in EAC to a greater extent than paclitaxel-H alone. The mechanism(s) underlying the chemosensitizing effect of yeast is not known, but could be attributed to the ability of yeast to suppress MDR proteins or increase the intracellular chemotherapy drug accumulation in cancer cells.

The immunomodulatory effect of $S$. cerevisiae may represent another mechanism by which this agent suppresses tumor growth in EAC-bearing mice. Results of this study showed the ability of yeast to act as a potent immune modulator, as indicated by enhancement of $\mathrm{CD}^{+}$and $\mathrm{CD}^{+} \mathrm{T}$ cell tumor infiltration. Earlier research has shown that yeast treatment can increase recruitment of leukocytes, including macrophages into the tumors, and modulate cytokine response, as indicated by elevation of TNF- $\alpha$ and IFN- $\gamma$ plasma levels and decreased IL-10 levels (32). This suggests that $S$. cerevisiae 
exerts anticancer effects via both apoptotic and immunomodulatory properties. The findings of this study also showed that paclitaxel enhanced tumor infiltration of $\mathrm{CD}^{+}$and $\mathrm{CD}^{+} \mathrm{T}$ cells but to a lesser extent than yeast.

The histopathological results of yeast treatment alone are in agreement with our previous results in which injection of S.cerevisiae into mice bearing EAC was associated with histopathology changes including extensive tumor necrosis, apoptosis and ischemic (coagulative) and liquefactive necrosis (32). In the present study, yeast in combination with paclitaxel-L resulted in increased tumor necrosis, decreased tumor aggressiveness and decreased tumor proliferative activity relative to treatment with either yeast or paclitaxel-L alone. Yeast plus paclitaxel-L showed a similar magnitude of tumor necrosis as compared to paclitaxel-H alone and yeast plus paclitaxel-H. Yeast plus paclitaxel-L also demonstrated fewer bizarre/multinucleated cells and mitoses than paclitaxel-H. Thus, yeast plus paclitaxel$\mathrm{L}$ is more effective against breast cancer than paclitaxel- $\mathrm{H}$.

$S$. cerevisiae is viewed as a safe, non-toxic, non-life threatening agent by the human population. In our previous in vitro study (28), we showed that yeast specifically affects cancer cells and not normal cells. When cultured with yeast, breast cancer cells (MCF-7) phagocytized the yeast and subsequently underwent apoptosis, while there was virtually no phagocytosis of yeast by the normal non-tumorgenic breast epithelial cells (MCF-10A). The safety of yeast treatment has been additionally examined using two in vivo approaches. In animal studies, S. cerevisiae showed no toxic characteristics as manifested by the ability of all animals to survive for 45 days post-treatment with yeast with normal feeding/drinking and life activity patterns (31). Mice treated with yeast survived a 16 -week treatment period and histopathology of different organs and biochemical analysis of liver and kidney function were within the limits of normal healthy mice (59). The work of others have also shown that animals can tolerate relatively high doses of yeast without any pathology detected up to at least 21 days post treatment, including rats (60), mice (61) and monkeys (62). Our current data are in accordance with the above mentioned studies, where mice survived a 30-day treatment period. In the second in vivo approach, human studies have shown that i.v. injections of yeast glucans have been given to humans to boost the immune system of patients undergoing major surgery (63-64), patients with Paracoccidioidomycosis (PCM), an endemic disease in most Latin American countries, and for elimination of $P$. brasiliensis (65). Results of these studies revealed no adverse side effects associated with yeast infusion $(63,64,66)$. A skin cancer study showed that treatment with yeast counteracted the significant decrease in body weight due to cancer (59). Weight loss is common among people with cancer, and it has been also observed in animal studies that adipose tissue wasting can occur as soon as the tumor is palpable (67).

In conclusion, baker's yeast can enhance the apoptotic effect of paclitaxel and may suggest the use of yeast as an adjuvant treatment during anticancer chemotherapy. These results may have clinical implications for the treatment of breast cancer. Future research needs to be directed towards examining the chemosensitizing effect of yeast in other models, such as the xenograft model. In addition, the ability of yeast as a chemosensitizer should be investigated in combination with other chemotherapeutic agents.

\section{Acknowledgements}

Not applicable.

\section{Funding}

The present study was partially supported by the National Institutes of Health-National Institute on Minority Health and Health Disparities (grant nos. U54MD007598 and S21MD000103).

\section{Availability of data and materials}

The datasets used and analyzed during the current study are available from the corresponding author on reasonable request.

\section{Authors' contributions}

MG and NKBED designed the experiments and analyzed and interpreted data. AZM analyzed and interpreted the data. LT carried out the histopathology analyses. DP contributed to the statistical analysis of the data. TAH performed the experiments and analyzed the data. All authors drafted, reviewed, edited, read and approved the manuscript and agree to be accountable for all aspects of the research in ensuring that the accuracy or integrity of any part of the work are appropriately investigated and resolved.

\section{Ethics approval and consent to participate}

Animal protocols were in compliance with the Guide for the Care and Use of Laboratory Animals at the University of Mansoura, Egypt and the experiments were approved by the University.

\section{Patient consent for publication}

Not applicable.

\section{Competing interests}

The authors declared that they have no competing interests.

\section{References}

1. Gligorov J and Lotz JP: Preclinical pharmacology of the taxanes: Implications of the differences. Oncologist 9 (Suppl 2): 3-8, 2004.

2. Guastalla JP, Lhommé C, Dauplat J, Namer M, Bonneterre J, Oberling F, Pouillart P, Fumoleau P, Kerbrat P, Tubiana N, et al: Taxol (paclitaxel) safety in patients with platinum pretreated ovarian carcinoma: An interim analysis of a phase II multicenter study. Ann Oncol 5 (Suppl 6): S33-S38, 1994.

3. Ohtsu T, Sasaki Y, Tamura T, Miyata Y, Nakanomyo H, Nishiwaki Y and Saijo N: Clinical pharmacokinetics and pharmacodynamics of paclitaxel: A 3-hour infusion versus a 24-hour infusion. Clin Cancer Res 1: 599-606, 1995.

4. Newman DJ, Cragg GM and Snader KM: Natural products as sources of new drugs over the period 1981-2002. J Nat Prod 66: 1022-1037, 2003.

5. Sylvester PW, Kaddoumi A, Nazzal S and El Sayed KA: The value of tocotrienols in the prevention and treatment of cancer. J Am Coll Nutr 29 (Suppl): 324S-333S, 2010.

6. Chen YJ: Potential role of tetrandrine in cancer therapy. Acta Pharmacol Sin 23: 1102-1106, 2002. 
7. Farina HG, Pomies M, Alonso DF and Gomez DE: Antitumor and antiangiogenic activity of soy isoflavone genistein in mouse models of melanoma and breast cancer. Oncol Rep 16: 885-891, 2006.

8. Rafieian-Kopaei M and Movahedi M: Breast cancer chemopreventive and chemotherapeutic effects of Camellia Sinensis (green tea): An updated review. Electron Physician 9: 3838-3844, 2017.

9. Badr El-Din NK, Noaman E and Ghoneum M: In vivo tumor inhibitory effects of nutritional rice bran supplement MGN-3 Biobran on Ehrlich carcinoma-bearing mice. Nutr Cancer 60 235-244, 2008.

10. Badr El-Din NK, Abdel Fattah SM, Pan D, Tolentino L and Ghoneum M: Chemopreventive activity of MGN-3/Biobran against chemical induction of glandular stomach carcinogenesis in rats and its apoptotic effect in gastric cancer cells. Integr Cancer Ther 15: NP26-NP34, 2016.

11. Pérez-Martínez A, Valentín J,FernándezL,Hernández-JiménezE, López-Collazo E, Zerbes P, Schwörer E, Nuñéz F, Martín IG, Sallis H, et al: Arabinoxylan rice bran (MGN-3/Biobran) enhances natural killer cell-mediated cytotoxicity against neuroblastoma in vitro and in vivo. Cytotherapy 17: 601-612, 2015.

12. Ghoneum M and Gollapudi S: Susceptibility of the human LNCaP prostate cancer cells to the apoptotic effect of marina crystal minerals (MCM) in vitro. Oncol Rep 22: 155-159, 2009.

13. Ghoneum M, Seto Y, Sato S, Ghoneum A, Braga M and Gollapudi S: Gross thymic extract, Thymax, induces apoptosis in human breast cancer cells in vitro through the mitochondrial pathway. Anticancer Res 28 (3A): 1603-1609, 2008.

14. Ghoneum M and Gimzewski J: Apoptotic effect of a novel kefir product, $\mathrm{PFT}$, on multidrug-resistant myeloid leukemia cells via a hole-piercing mechanism. Int J Oncol 44: 830-837, 2014.

15. Gollapudi S and Ghoneum M: MGN-3/Biobran, modified arabinoxylan from rice bran, sensitizes human breast cancer cells to chemotherapeutic agent, daunorubicin. Cancer Detect Prev 32: 1-6, 2008.

16. Ghoneum M: Wheat and rice in disease prevention and health. In: Apoptosis and Arabinoxylan Rice Bran. Watson RR, Preedy V and Zibadi S (eds). Elsevier Science \& Technology Book, pp399-404, 2014.

17. Endo $\mathrm{Y}$ and Kanbayashi H: Modified rice bran beneficial for weight loss of mice as a major and acute adverse effect of Cisplatin. Pharmacol Toxicol 92: 300-303, 2003.

18. Jacoby HI, Wnorowski G, Sakata K and Maeda H: The effect ofMGN-3 on cisplatin and doxorubicin induced toxicity in the rat. J. Nutraceuticals Funct Med Foods 3: 3-11, 2001

19. Bang MH, Van Riep T, Thinh NT, Song H, Dung TT, Van Truong L, Van Don L, Ky TD, Pan D, Shaheen M, et al: Arabinoxylan rice bran (MGN-3) enhances the effects of interventional therapies for the treatment of hepatocellular carcinoma: A three-year randomized clinical trial. Anticancer Res 30: 5145-5151, 2010.

20. Goel A and Aggarwal BB: Curcumin, the golden spice from Indian saffron, is a chemosensitizer and radiosensitizer for tumors and chemoprotector and radioprotector for normal organs. Nutr Cancer 62: 919-930, 2010.

21. Limtrakul P: Curcumin as chemosensitizer. Adv Exp Med Biol 595: 269-300, 2007.

22. Rege BD, Kao JP and Polli JE: Effects of nonionic surfactants on membrane transporters in Caco-2 cell monolayers. Eur J Pharm Sci 16: 237-246, 2002.

23. Tian $\mathrm{H}$ and Pan QC: A comparative study on effect of two bisbenzylisoquinolines, tetrandrine and berbamine, on reversal of multidrug resistance. Yao Xue Xue Bao 32: 245-250, 1997 (In Chinese).

24. Choi SU, Park SH, Kim KH, Choi EJ, Kim S, Park WK, Zhang YH, Kim HS, Jung NP and Lee CO: The bisbenzylisoquinoline alkaloids, tetrandine and fangchinoline, enhance the cytotoxicity of multidrug resistance-related drugs via modulation of P-glycoprotein. Anticancer Drugs 9: 255-261, 1998.

25. Chen C, Zhou J and Ji C: Quercetin: A potential drug to reverse multidrug resistance. Life Sci 87: 333-338, 2010.

26. Ghoneum M and Gollapudi S: Induction of apoptosis in breast cancer cells by Saccharomyces cerevisiae, the baker's yeast, in vitro. Anticancer Res 24 (3a): 1455-1463, 2004

27. Ghoneum M and Gollapudi S: Modified arabinoxylan rice bran (MGN-3/Biobran) enhances yeast-induced apoptosis in human breast cancer cells in vitro. Anticancer Res 25 (2A): 859-870, 2005.

28. Ghoneum M and Gollapudi S: Synergistic role of arabinoxylan rice bran (MGN-3/Biobran) in S. cerevisiae-induced apoptosis of monolayer breast cancer MCF-7 cells. Anticancer Res 25 (6B): 4187-4196, 2005
29. Ghoneum M, Hamilton J, Brown J and Gollapudi S: Human squamous cell carcinoma of the tongue and colon undergoes apoptosis upon phagocytosis of Saccharomyces cerevisiae, the baker's yeast, in vitro. Anticancer Res 25 (2A): 981-989, 2005.

30. Ghoneum M, Brown J and Gollapudi S: 'Yeast therapy for the treatment of cancer and its enhancement by MGN-3/Biobran, an arabinoxylan rice bran' in apoptosis review. Nova Science Publishers, Inc., Hauppague, NY, pp185-200, 2007.

31. Ghoneum M, Wang L, Agrawal S and Gollapudi S: Yeast therapy for the treatment of breast cancer: A nude mice model study. In Vivo 21: 251-258, 2007.

32. Ghoneum M, Badr El-Din NK, Noaman E and Tolentino L: Saccharomyces cerevisiae, the Baker's Yeast, suppresses the growth of Ehrlich carcinoma-bearing mice. Cancer Immunol Immunother 57: 581-592, 2008.

33. Yarkoni E, Lederer E and Rapp HJ: Immunotherapy of experimental cancer with a mixture of synthetic muramyl dipeptide and trehalose dimycolate. Infect Immun 32: 273-276, 1981.

34. Badr El-Din NK, Mahmoud AZ, Hassan TA and Ghoneum M: Baker's yeast sensitizes metastatic breast cancer cells to paclitaxel in vitro. Integr Cancer Ther 17: 542-550, 2018.

35. Calixto-Campos C, Zarpelon AC, Corrêa M, Cardoso RD, PinhoRibeiro FA, Cecchini R, Moreira EG, Crespigio J, Bernardy CC, Casagrande R, et al: The Ehrlich tumor induces pain-like behavior in mice: A novel model of cancer pain for pathophysiological studies and pharmacological screening. BioMed Res Int 2013: 624815,2013

36. Ehrlich and Apolant. Beobachtungen Über Maligne Mausentumoren. Berlin. Klin Wochenschr 28: 871-874, 1905 (In German).

37. Kaleoğlu Ö and İşli N: Ehrlich -Lettre Asit Tümörü. Tip Fak Mecm 40: 978-984, 1977 (In Turkish).

38. Mishra S, Tamta AK, Sarikhani M, Desingu PA, Kizkekra SM, Pandit AS, Kumar S, Khan D, Raghavan SC and Sundaresan NR: Subcutaneous Ehrlich ascites carcinoma mice model for studying cancer-induced cardiomyopathy. Sci Rep 8: 5599, 2018.

39. Cattoretti G, Becker MH, Key G, Duchrow M, Schlüter C, Galle J and Gerdes J: Monoclonal antibodies against recombinant parts of the Ki-67 antigen (MIB 1 and MIB 3) detect proliferating cells in microwave-processed formalin-fixed paraffin sections. J Pathol 168: 357-363, 1992

40. Reynolds ES: The use of lead citrate at high $\mathrm{pH}$ as an electron microscopy. J Cell Biol 17: 208-212, 1963.

41. Marupudi NI, Han JE, Li KW, Renard VM, Tyler BM and Brem H: Paclitaxel: A review of adverse toxicities and novel delivery strategies. Expert Opin Drug Saf 6: 609-621, 2007.

42. Gustafson DL, Long ME, Zirrolli JA, Duncan MW, Holden SN, Pierson AS and Eckhardt SG: Analysis of docetaxel pharmacokinetics in humans with the inclusion of later sampling time-points afforded by the use of a sensitive tandem LCMS assay. Cancer Chemother Pharmacol 52: 159-166, 2003.

43. Xu G, Pan J, Martin C and Yeung S-CJ: Angiogenesis inhibition in the in vivo antineoplastic effect of manumycin and paclitaxel against anaplastic thyroid carcinoma. J Clin Endocrinol Metab 86: $1769-1777,2001$.

44. Stassi G, Todaro M, Zerilli M, Ricci-Vitiani L, Di Liberto D, Patti M, Florena A, Di Gaudio F, Di Gesù G and De Maria R: Thyroid cancer resistance to chemotherapeutic drugs via autocrine production of interleukin-4 and interleukin-10. Cancer Res 63: 6784-6790, 2003.

45. Piñeiro D, Martín ME, Guerra N, Salinas M and González VM: Calpain inhibition stimulates caspase-dependent apoptosis induced by taxol in NIH3T3 cells. Exp Cell Res 313: 369-379, 2007.

46. Potemski P and Płuzańska A: Pharmacological action of paclitaxel. Pol Merkur Lekarski 6: 27-29, 1999 (In Polish).

47. Badr El-Din NK, Ali DA, Alaa El-Dein M and Ghoneum M: Enhancing the apoptotic effect of a low dose of paclitaxel on tumor cells in mice by arabinoxylan rice bran (MGN-3/Biobran). Nutr Cancer 68: 1010-1020, 2016.

48. Ghoneum M, Matsuura M, Braga M and Gollapudi S: S. cerevisiae induces apoptosis in human metastatic breast cancer cells by altering intracellular $\mathrm{Ca}_{2}^{+}$and the ratio of $\mathrm{Bax}$ and $\mathrm{Bcl}-2$. Int J Oncol 33: 533-539, 2008.

49. Jordan MA and Wilson L: The use and action of drugs in analyzing mitosis. Methods Cell Biol 61: 267-295, 1999.

50. Morse DL, Gray H, Payne CM and Gillies RJ: Docetaxel induces cell death through mitotic catastrophe in human breast cancer cells. Mol Cancer Ther 4: 1495-1504, 2005. 
51. Ghoneum M, Badr El-Din NK, Ali DA and El-Dein MA: Modified arabinoxylan from rice bran, MGN-3/biobran, sensitizes metastatic breast cancer cells to paclitaxel in vitro. Anticancer Res 34: 81-87, 2014

52. Yu XJ, Sun K, Tang XH, Zhou CJ, Sun H, Yan Z, Fang L, Wu HW, Xie YK and Gu B: Harmine combined with paclitaxel inhibits tumor proliferation and induces apoptosis through downregulation of cyclooxygenase-2 expression in gastric cancer. Oncol Lett 12: 983-988, 2016.

53. Gonçalves A, Braguer D, Carles G, André N, Prevôt C and Briand C: Caspase-8 activation independent of CD95/CD95-L interaction during paclitaxel-induced apoptosis in human colon cancer cells (HT29-D4). Biochem Pharmacol 60: 1579-1584, 2000

54. Peng ZG, Liu DC, Yao YB, Feng XL, Huang X, Tang YL, Yang J and Wang XX: Paclitaxel induces apoptosis in leukemia cells through a JNK activation-dependent pathway. Genet Mol Res 15: $15013904,2016$.

55. Varbiro G, Veres B, Gallyas F Jr and Sumegi B: Direct effect of Taxol on free radical formation and mitochondrial permeability transition. Free Radic Biol Med 31: 548-558, 2001.

56. Roy M and Mukherjee S: Reversal of resistance towards cisplatin by curcumin in cervical cancer cells. Asian Pac J Cancer Prev 15: $1403-1410,2014$

57. Abulrob AN, Mason M, Bryce R and Gumbleton M: The effect of fatty acids and analogues upon intracellular levels of doxorubicin in cells displaying P-glycoprotein mediated multidrug resistance. J Drug Target 8: 247-256, 2000.

58. Gelsomino G, Corsetto PA, Campia I, Montorfano G, Kopecka J, Castella B, Gazzano E, Ghigo D, Rizzo AM and Riganti C: Omega 3 fatty acids chemosensitize multidrug resistant colon cancer cells by down-regulating cholesterol synthesis and altering detergent resistant membranes composition. Mol Cancer 12: 137, 2013.

59. Elwakkad A, Ghoneum M, El-sawi M, Mohamed SI, Gamal el Din AA, Pan D and Elqattan GM: Baker's yeast induces apoptotic effects and histopathological changes on skin tumors in mice. Cogent Med 5: 1437673, 2018.
60. Fahrig R: Development of host-mediated mutagenicity testsyeast systems. II. Recovery of yeast cells out of testes, liver, lung, and peritoneum of rats. Mutat Res 31: 381-394, 1975.

61. Frezza D, Zeiger E and Gupta BN: The intrasanguineous hostmediated assay procedure distribution and retention of yeast in the mouse. Mutat Res 64: 295-305, 1979.

62. Maejima K, Shimoda K, Morita C, Fujiwara T and Kitamura T: Colonization and pathogenicity of Saccharomyces cerevisiae, $\mathrm{MC16}$, in mice and cynomolgus monkeys after oral and intravenous administration. Jpn J Med Sci Biol 33: 271-276, 1980.

63. Babineau TJ, Marcello P, Swails W, Kenler A, Bistrian B and Forse RA: Randomized phase I/II trial of a macrophage-specific immunomodulator (PGG-glucan) in high-risk surgical patients. Ann Surg 220: 601-609, 1994.

64. Babineau TJ, Hackford A, Kenler A, Bistrian B, Forse RA, Fairchild PG, Heard S, Keroack M, Caushaj P and Benotti P: A phase II multicenter, double-blind, randomized, placebo-controlled study of three dosages of an immunomodulator (PGG-glucan) in high-risk surgical patients. Arch Surg 129: 1204-1210, 1994.

65. Wanke B and Londero AT: Epidemiology and paracoccidioidomycosis infection. In: Paracoccidioidomycosis. Franco M, Lacaz CS, Restrepo-Moreno A and Del Negro G (eds). CRC Press, Boca Raton, pp109-120, 1994.

66. Meira DA, Pereira PC, Marcondes-Machado J, Mendes RP, Barraviera B, Pellegrino Júnior J, Rezkallah-Iwasso MT, Peracoli MT, Castilho LM, Thomazini I, et al: The use of glucan as immunostimulant in the treatment of paracoccidioidomycosis. Am J Trop Med Hyg 55: 496-503, 1996.

67. Costa G and Holland JF: Effects of Krebs-2 carcinoma on the lipide metabolism of male Swiss mice. Cancer Res 22: 1081-1083, 1962.

This work is licensed under a Creative Commons Attribution-NonCommercial-NoDerivatives 4.0 International (CC BY-NC-ND 4.0) License. 